\title{
Reproductive biology of the spiny lobster, Panulirus Penicillatus, in the southeastern coastal waters off Taiwan
}

\author{
Yi-Jay Chang $\cdot$ Chi-Lu Sun $\cdot$ Yong Chen · \\ Su-Zan Yeh $\cdot$ Wei-Chuan Chiang
}

Received: 30 May 2006/ Accepted: 12 September 2006/Published online: 21 October 2006

(C) Springer-Verlag 2006

\begin{abstract}
The reproductive biology of spiny lobster, Panulirus penicillatus, was studied based on 2,068 lobsters, ranging from 34.28 to $131.60 \mathrm{~mm}$ carapace length (CL), sampled in Taitung coastal waters from September 2003 to December 2004. The overall sex ratio approximated $1: 1\left(\chi^{2}=0.02, P>0.05\right)$, but the monthly sex ratios in 2004 showed significant differences and males were predominant in sizes larger than $80 \mathrm{~mm}$ CL. Reproductive activity, assessed using histology, a gonadosomatic index and percentage of ovigerous females, indicated that the mature females could be found in every month and that the major spawning occurred from May to September. The presence of re-developing/reripe ovaries by month and size-specific spawning time suggest that larger mature females ( $>60 \mathrm{~mm} \mathrm{CL})$ spawn at least three times a year while smaller new mature females spawn at least once a year. For females, the estimated sizes at $50 \%$ physiological and functional maturity were (mean $\pm \mathrm{SE}$ ) $56.46 \pm 0.56 \mathrm{~mm} \mathrm{CL}$ and $66.63 \pm 1.07 \mathrm{~mm} \mathrm{CL}$. The estimated sizes at functional maturity were between 72 and $74 \mathrm{~mm}$ CL for males.
\end{abstract}

Communicated by S. Nishida, Tokyo.

Y.-J. Chang · C.-L. Sun ( () ) S.-Z. Yeh

Institute of Oceanography, National Taiwan University,

1 Sec 4 Roosevelt Rd, Taipei 106, Taiwan

e-mail: chilu@ntu.edu.tw

Y. Chen

School of Marine Science, University of Maine,

218 Libby Hall, Orono, ME 04469, USA

\section{W.-C. Chiang}

Eastern Marine Biology Research Center of Fisheries

Research Institute, Council of Agriculture,

Executive Yuan, Taipei, Taiwan
The number of eggs per spawning event (brood size, BS) was related to $\mathrm{CL}$ by the equation $Y_{\mathrm{BS}}=2.4 \times 10^{-3}$ $\mathrm{CL}^{4.18}\left(r^{2}=0.902, n=12\right)$. Female lobsters with $\mathrm{CL}$ ranging from 60 to $80 \mathrm{~mm}$ made the greatest contributions to egg production because of their high brood size and active reproductive activity. A minimum legal size should be established for the fishery to protect egg production potential of lobster population in the southeastern coastal waters off Taiwan.

Keywords Panulirus penicillatus · Taitung - Ovarian development - Spawning time - Size at maturity ·

Brood size $\cdot$ Relative reproductive potentials

\section{Introduction}

The spiny lobster, Panulirus penicillatus, is widely distributed in the Indo-West Pacific. It is a shallow water species and mainly inhabits the upper 4-5 $\mathrm{m}$ on outer reef slopes in the tropical Pacific (George 1972). The spiny lobster is an important commercial species in the southeastern coastal water off Taiwan (Taitung), where it is caught by skin-diving or trammels net throughout the year. The spiny lobster fishery is managed with a minimum size limit of $20 \mathrm{~cm}$ total length or about $73.07 \mathrm{~mm}$ carapace length (CL) for all species along the coast of Taiwan (Taiwan Provincial Government 1987). However, this regulation is not derived from any consideration of reproductive biology and other life history processes and has not been strictly enforced. Small lobsters or berried females were common in the fish markets. This lack of protection of spawners could damage reproductive potential of the lobster population, resulting in recruitment failure and 
overexploitation. In fact, the average size of the lobster population has been seen decreasing over the last decade.

Despite the importance of the $P$. penicillatus fisheries in the Indo-West Pacific, information about its key life history parameters is limited. Its reproductive biology (i.e., size at maturity and brood size) has been previously studied for the $P$. penicillatus population in Hawaii (Morris 1968; McGinnis 1972; MacDonald 1979), Palau (MacDonald 1988), Philippines (Juinio 1987) and Red sea (Plaut 1993; Hogarth and Barratt 1996). However, all these studies except for Juinio (1987) only used the external morphological indicators such as berried conditions to determine the maturity and provided no estimates of size at physiological maturity and macroscopic description of ovarian development. Large variations in reproductive pattern were reported across the specie's spatial distribution. To determine a sustainable level of fishing mortality for spiny lobster, we need to derive information on key population parameters, particularly those concerning the reproductive biology of the species in the Taiwan coastal waters.

The objective of this study is to evaluate the reproductive biology and its dynamics of $P$. penicillatus in the southeastern coastal waters off Taiwan (i.e., Taitung). We determined the reproductive activity based on histological techniques and provided a detailed description of ovarian development. Key parameters required in stock assessment including sex ratio, reproductive season, size at maturity and brood size were also evaluated and estimated.

\section{Materials and methods}

\section{Sample collection}

Samples were randomly collected from the catch in trammel nets and skin diving fisheries, monthly in Taitung (Fig. 1) during September 2003 to December 2004. For each lobster the carapace length, from the tip of the rostral spine to the posterior edge, was measured to the nearest $0.01 \mathrm{~mm}$. Sex, reproductive state, the presence of external eggs and spermatophore condition, were recorded on the day of collection. A total of eighteen $5 \mathrm{~mm}^{3}$ small ovary samples from pair ovaries of three lobsters, were obtained from three sections (anterior, middle and posterior) of each ovary lobe. Oocytes from each section were measured using a computerized image analyzing system (Image Pro-Plus v. 5.0) linked to a microscope. Applying a split-plot ANOVA, we found that there were no significant differences in the size of oocytes between lobes in each ovary $\left(F_{1,24}=0.54, P>0.05\right)$. This was expected as both ovary lobes were at the same stage of oocyte development. About 20 ovary samples were dissected every month from January 2004 to December 2004. Each ovary was weighted and fixed in Bouin's solution, sectioned at $7 \mu \mathrm{m}$ and stained with Mayer's haematoxylin and Eosin. Egg masses were removed from berried females for fecundity estimation.

Gonad maturation and breeding period determination

The stage of ovary maturity was determined based on Minagawa and Sano (1997) and Juinio (1987). According to the most advanced group of oocytes present in the sample, we classified the five stages of maturity as (1) immature stage, (2) developing/redeveloping stage, (3) ripe/re-ripe stage, (4) spent stage, (5) recovery stage. A gonadosomatic index (GSI) was determined for an individual female (Minagawa 1997) as

$\mathrm{GSI}=\frac{W_{\mathrm{g}}}{C L^{3}} \times 10^{5}$

where $W_{\mathrm{g}}$ represents the gonad weight $(\mathrm{g})$, and CL is the carapace length.

The spawning time was determined by the following three methods: (1) the temporal development of the ovaries in females (Juinio 1987; Chubb 2000), (2) the evolution of temporal changes in females' GSI (Juinio 1987; Plaut 1993; Goñi et al. 2003), and (3) seasonal

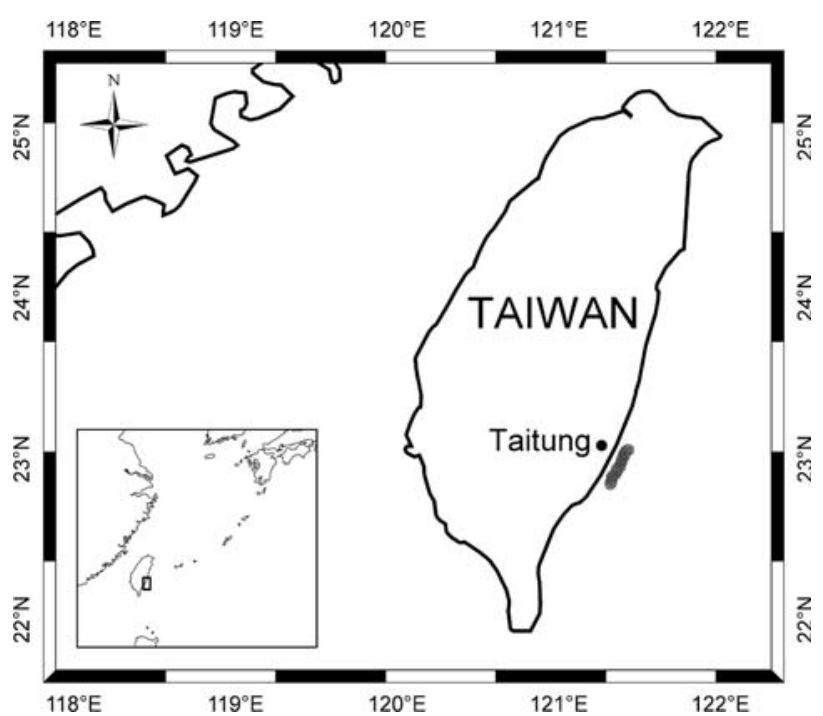

Fig. 1 Map of the study area showing the location (spotted zone) where the spiny lobster Panulirus penicillatus was sampled 
changes in the composition of ovigerous females (Minagawa 1997).

Size at maturity

The size for physiological maturity is defined as the size at which ovaries are in developing stage or higher during reproductive season, and the size for functional maturity is defined as the size at which females are involved in the reproductive activity and berried (Evans et al. 1995).

For female lobsters, the size at which $50 \%$ of all individuals are physiologically and functionally mature $\left(\mathrm{CL}_{50}\right)$ was determined from modeling size-specific proportion of mature ovaries in each $5 \mathrm{~mm}$ CL class and external reproductively active individuals in each $3 \mathrm{~mm}$ CL class, respectively. A conventional logistic model (Minagawa 1997; Goñi et al. 2003) was used to quantify such a relationship:

$P=\frac{1}{1+\exp \left[r \times\left(C L-C L_{50}\right)\right]}$

where $P$ is the proportion of mature individuals within a size class, $r$ is the slope of the curve, and $\mathrm{CL}_{50}$ is the size (CL) at $50 \%$ sexual maturity, and CL is carapace length. $\mathrm{CL}_{50}$ and $r$ were estimated using the nonlinear least square procedure (Chambers and Hastie 1992) implemented with the S-Plus (MathSoft Inc.).

For male lobsters, it is not possible to determine physiological maturity from external characteristics or the macroscopic appearance of the testes (Aiken and Waddy 1980; Chubb 2000). Thus, the functional maturity for males was based on the onset of allometric growth of the walking leg (George and Morgan 1979). It is difficult to make precise measurement of the whole walking leg, thus in present study measurements were made for the meropodite length (the longest segment of the limb) of the right walking leg (Evans et al. 1995). The initiation of allometric growth was determined by plotting the second and third meropodite length against the carapace length. The lowest combined residual sum of square for paired regressions indicated the point of onset of allometric growth, which is the size at maturity for males defined by Somerton (1980) and Lovett and Felder (1989). For females, the same method was attempted for estimating the size at maturity. After determination of the inflection point, the following $F$-statistics was calculated.

$F=\frac{\left(R S S_{1} \text { line }-R S S_{2} \text { line }\right) / 2}{R S S_{2} \text { line } /(N-4)}$ where $\mathrm{RSS}_{1}$ line is the residual sum of square (RSS) of fitting a single regression model to the data, $\mathrm{RSS}_{2}$ line is the RSS of fitting two regression models to the data and $N$ is the number of data points. This $F$-statistics was then compared with critical $F$ value for determining if the resulting two regression models fit the data better than a single regression model (Somerton 1980). Analysis of covariance (ANCOVA) was used to evaluate whether the slopes of the regression lines were significantly different (Minagawa and Higuchi 1997).

\section{Brood size}

Brood size is defined as the number of eggs carried externally on the pleopods of once spawning (Pollock and Goosen 1991). Twelve egg masses in the early stage of development (Beyers and Goosen 1987) borne by females selected to cover a wide size range were collected for brood size estimates (Juinio 1987). Egg masses were cleaned of non-egg material and ovendried at $80^{\circ} \mathrm{C}$ for $4-5 \mathrm{~h}$ (Gomez et al. 1994). The total dried weight was determined to the nearest $0.0001 \mathrm{~g}$ with an electronic balance. The mean number of eggs in three $0.01 \mathrm{~g}$ subsamples per egg batch was used to calculate brood size and relative brood size (i.e., egg per body gram, Hobday and Ryan 1997; Goñi et al. 2003).

\section{Relative reproductive potential}

The relative reproductive potential (RRP) was estimated for $P$. penicillatus as follows:

$\mathrm{RRP}=C_{i} \times M_{i} \times B_{i}$

where $C_{i}$ is the proportion of the size-class $i$ in all females, $M_{i}$ is the proportion of ovigerous females in size-class $i$, and $B_{i}$ is the mean brood size of females in size-class $i$ (Hobday and Ryan 1997; Goñi et al. 2003).

\section{Results}

Size distribution and sex ratio

From January 2003 to December 2004, a total of 2068 $P$. penicillatus were randomly sampled along the Taitung coast, of which 1,031 were male and 1,037 were female. Most males sampled had sizes ranging from 40 to $60 \mathrm{~mm} \mathrm{CL}$, females were from 40 to $65 \mathrm{~mm} \mathrm{CL}$ and ovigerous from 45 to $80 \mathrm{~mm} \mathrm{CL}$ (Fig. 2). 
The sex ratio fluctuated from 0.4 to 0.6 without a systematic pattern at a CL of less than $80 \mathrm{~mm}$, but the proportion of females decreased with $\mathrm{CL}$ when $\mathrm{CL}$ was greater than $80 \mathrm{~mm}$. The sex ratios remained between 0.4 and 0.6 , irrespective of the month. The overall sex ratio did not differ significantly from 0.5 during the sampling period $\left(\chi^{2}=0.02, P>0.05\right)$. However, more females occurred in the samples collected in June, July and September $($ mean $=0.58 ; \mathrm{SE}=0.006)$.

Oocyte and ovary development

The developmental stage of almost all oocytes in the anterior, middle and posterior areas of ovaries was isochronal, and the oocyte frequency distribution (Fig. 3) indicated an apparent mode moving with the ovarian development. This suggests that almost all the oocytes in an ovary are spawned at the same time. Based on microscopic characteristics, seven oogenesis stages were defined for the spiny lobster (Table 1 , Fig. 4).

The gonads were collected from 157 females of size ranges from 43.60 to $90.34 \mathrm{~mm} \mathrm{CL}$. Based on the oocyte development, GSI and macroscopic examination by the naked eye, we developed a classification scheme for the ovary development of female lobster (Table 2). For females, ovaries classified as the developing or later stages in maturation were categorized as physiologically mature.

\section{Reproductive activity}

The GSI of females increased from 0.46 in April to the peak of 1.36 in May, decreased thereafter to the lowest value of 0.31 in October, and then gradually increased (Fig. 5).

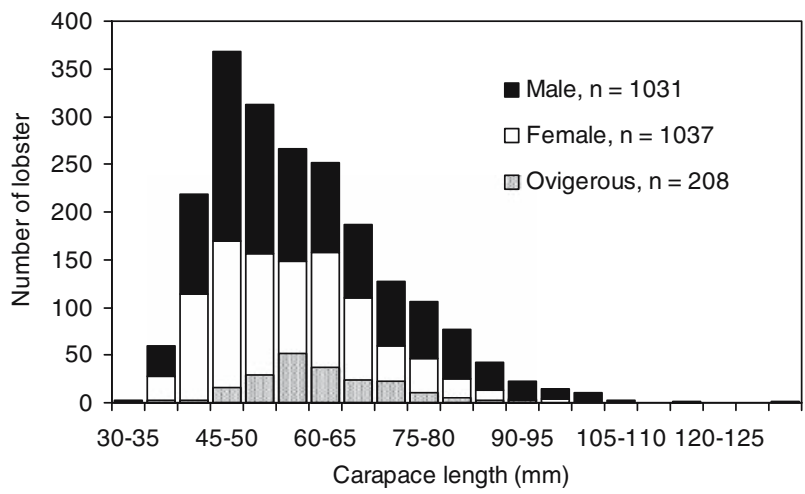

Fig. 2 Length-frequency distribution of the spiny lobster Panulirus penicillatus sampled in Taitung between September 2003 and December 2004
Egg-bearing females were observed from September 2003 to December 2003 and throughout 2004. A sizespecific spawning time was observed by dividing carapace lengths into three classes (Fig. 6). The proportion of size combined ovigerous females were high from April to July, peaked in June (50\%), and then deceased in August. The smallest size of ovigerous females found in this study was $43.53 \mathrm{~mm}$ CL.
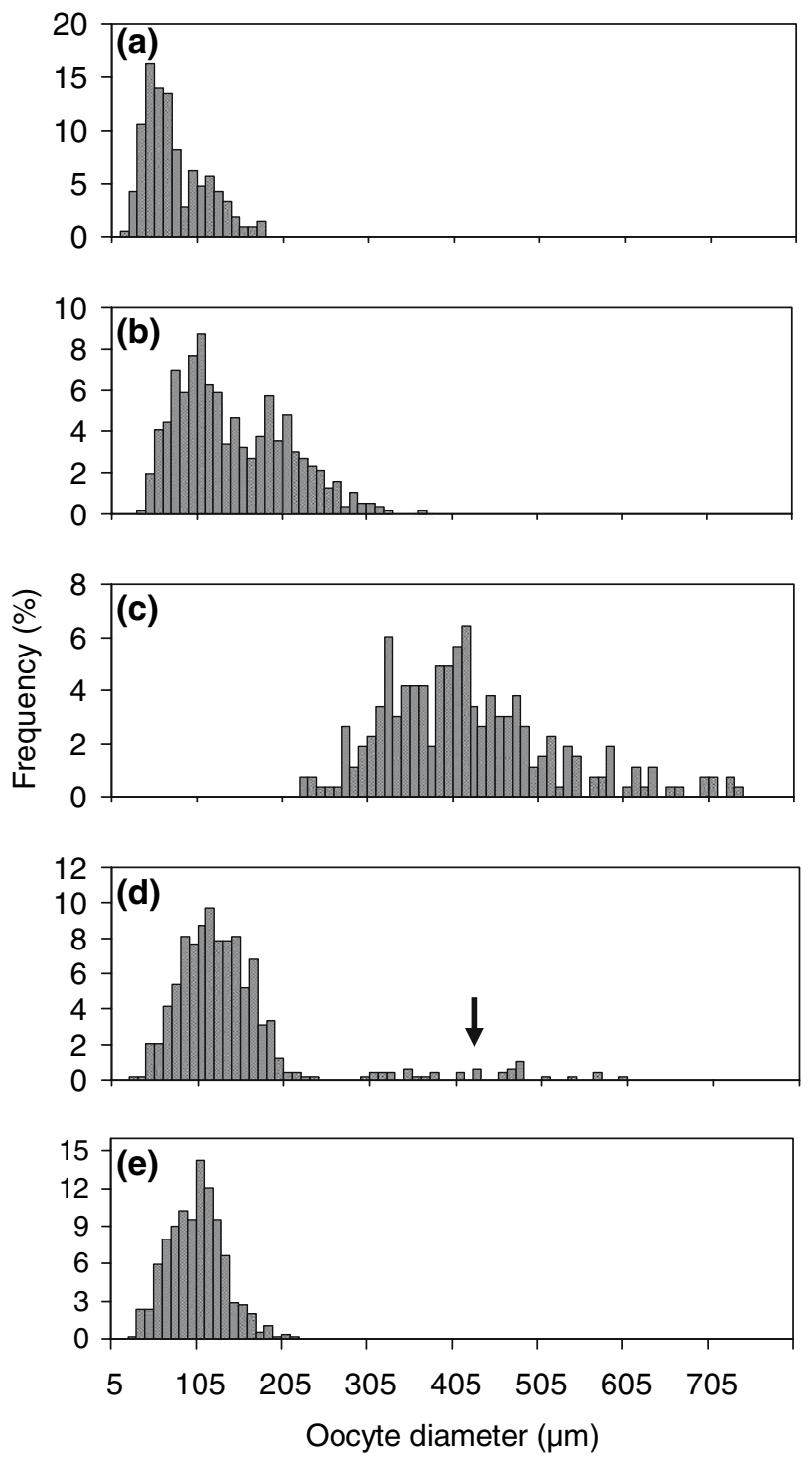

Fig. 3 Individual lobster oocyte diameter distribution at different stages of ovarian development obtained from histological section. a Inactive stage $(52.51 \mathrm{~mm} \mathrm{CL})$ with most advanced group of oocytes (MAGO) in pre-yolk platelet stage, b developing stage $(56.08 \mathrm{~mm} \mathrm{CL})$ with MAGO in yolk platelet stage, c ripe stage $(66.56 \mathrm{~mm} \mathrm{CL})$ with $\mathrm{MAGO}$ in pre-mature and maturation stage, $\mathbf{d}$ spent stage $(76.71 \mathrm{~mm} \mathrm{CL})$ with MAGO in maturation and yolk platelet stage, e recovery stage (63.37 mm CL) with MAGO in pre-yolk platelet stage. (Arrow indicates the residual oocytes) 
Table 1 Stages of oogenesis and their microscopic characteristics in the spiny lobster Panulirus penicillatus

\begin{tabular}{llcl}
\hline Oogenesis stage & $\begin{array}{l}\text { Oocyte diameter } \\
(\text { mean } \pm \mathrm{SE} \mu \mathrm{m})\end{array}$ & $\begin{array}{l}\text { Nucleus diameter } \\
(\text { mean } \pm \mathrm{SE} \mu \mathrm{m})\end{array}$ & $\begin{array}{l}\text { Follicle cell } \\
(\mathrm{mean} \pm \mathrm{SE} \mu \mathrm{m})\end{array}$ \\
\hline $\begin{array}{l}\text { Multiplication } \\
\text { Oogonium (I) }\end{array}$ & $10.54 \pm 0.35$ & $7.46 \pm 0.16$ & - \\
$\begin{array}{l}\text { Pre-vitellogenesis } \\
\quad \text { Chromatin nucleolus (II) }\end{array}$ & $18.51 \pm 0.39$ & $13.8 \pm 0.93$ & - \\
$\quad$ Vitellogenesis & $46.41 \pm 1.59$ & $17.99 \pm 0.74$ & $3.98 \pm 0.43$ \\
$\quad \begin{array}{l}\text { Oil globule (III) } \\
\text { Pre-yolk platelet (IV) }\end{array}$ & $130.27 \pm 3.17$ & $36.31 \pm 0.74$ & $3.8 \pm 0.14$ \\
$\quad$ Yolk platelet (V) & $239.61 \pm 5.44$ & $48.65 \pm 1.56$ & $2.72 \pm 0.21$ \\
$\quad$ Pre-mature (VI) & $428.82 \pm 12.40$ & $47.33 \pm 1.48$ & $2.6 \pm 0.12$ \\
$\quad \begin{array}{l}\text { Maturation } \\
\quad \text { Maturation (VII) }\end{array}$ & $590.64 \pm 25.65$ & - & $2.52 \pm 0.16$ \\
\hline
\end{tabular}

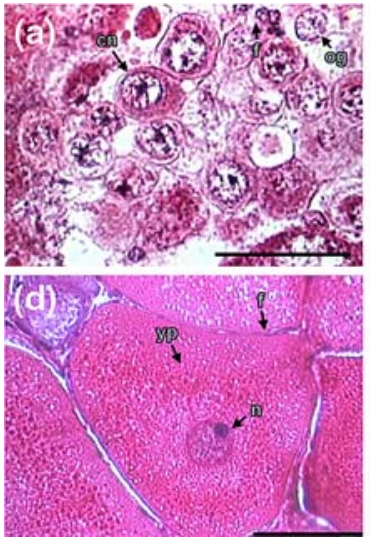

Fig. 4 Histological section illustrating oocytes at different maturity stages of the spiny lobster Panulirus penicillatus: a Oogonia and chromatin nucleolus stage, with a large central nucleus (Scale bar $=50 \mu \mathrm{m})$; b Oil globule stage, with one or two large oil globules appearing near the nucleolus; c Pre-yolk platelet stage, globules diffuse peripherally; d Yolk platelet stage, the nucleus diameter reaches its maximum; e Pre-mature stage, the nucleus becomes shrunk; f Maturation stage, the oocyte diameter reaches maximum and follicle cells are hardly visible. (Scale bar $=100 \mu \mathrm{m}$, og oogonia, $c n$ oocyte at the chromatin nucleolus stage, $f$ follicle cell, $o$ oil globule, $n$ nucleus, $n u$ nucleolus, yp yolk platelet, mo mature oocyte)
Ovarian development corresponded well with the changes in GSI and ovigerous percentage (Fig. 7). The ovaries in developing stage were observed from February to November, and peaked in August (50\%). Individuals with the ovaries in ripe stage appeared from January to March and May to December. Higher percentages were found in May through July, and peaked in June (36\%). The presence of immature and recovery stage ovaries were observed year-round. The re-developing or re-ripe stage ovaries were found in March, and May to July

Size at $50 \%$ maturity

A total of 157 females with a size range from 43.60 to $90.34 \mathrm{~mm} \mathrm{CL}$ were used to estimate size at physiological maturity. Changes in the proportion of physiologically mature females with size class $(5 \mathrm{~mm}$ intervals) were described by the logistic curve for estimating the $\mathrm{CL}_{50}$ as:

$P=\frac{1}{1+\exp [-0.28 \times(C L-56.46)]}$

$r^{2}=0.983$ and $n=157$. The mean and standard error for the $\mathrm{CL}$ at physiological maturity $\mathrm{CL}_{50}$ were $56.46 \pm 0.56 \mathrm{~mm}$ CL (mean \pm SE) (Fig. 8).

Carapace length at functional maturity was estimated based on the presence of berried eggs or spermatophore using the data collected in 20032004 ,

$P=\frac{1}{1+\exp [-0.11 \times(C L-66.63)]}$ 
Table 2 Classification and description of macroscopic and microscopic ovary stages of spiny lobster Panulirus penicillatus

\begin{tabular}{|c|c|c|c|c|c|}
\hline Ovarian stage & Macroscopic appearance & $\begin{array}{l}\text { Histological } \\
\text { characteristics }\end{array}$ & $\begin{array}{l}\text { GSI } \\
(\text { mean } \pm \text { SE })\end{array}$ & $n$ & $\begin{array}{l}\text { Most advanced } \\
\text { oocyte substage }\end{array}$ \\
\hline Inactive & $\begin{array}{l}\text { Ovaries were white rod-like, } \\
\text { occupying a small part of the } \\
\text { cephalothoracic cavity }\end{array}$ & $\begin{array}{l}\text { Oocytes protrude from the } \\
\text { germinal nest to the periphery } \\
\text { of an ovary }\end{array}$ & $0.22 \pm 0.03$ & 40 & Pre-yolk platelet \\
\hline $\begin{array}{c}\text { Developing/re- } \\
\text { developing }\end{array}$ & $\begin{array}{l}\text { The ovary increased in size and } \\
\text { turned light orange or orange } \\
\text { as the ova developed }\end{array}$ & $\begin{array}{l}\text { The ovarian wall was thin, more } \\
\text { mature ova radiated towards } \\
\text { the ovarian wall. Re- } \\
\text { developing ovary had thicker } \\
\text { ovarian wall than developing } \\
\text { ovary and the oocytes were } \\
\text { scattered }\end{array}$ & $\begin{array}{l}1.04 \pm 0.12 \\
1.13 \pm 0.24^{\mathrm{a}}\end{array}$ & $\begin{array}{l}25 \\
7^{\mathrm{a}}\end{array}$ & $\begin{array}{l}\text { Yolk-platelet } \\
\text { Yolk-platelet }^{\text {a }}\end{array}$ \\
\hline Ripe/re-ripe & $\begin{array}{l}\text { The swollen dark orange ovaries } \\
\text { occupied a large part of the } \\
\text { cephalothoracic cavity }\end{array}$ & $\begin{array}{l}\text { The pre-mature and mature } \\
\text { oocytes were tightly packed } \\
\text { together, thus distorted in } \\
\text { shape. The re-ripe ovaries } \\
\text { were similar to those in ripe } \\
\text { stages }\end{array}$ & $\begin{array}{l}3.7 \pm 0.37 \\
2.37 \pm 0.43^{b}\end{array}$ & $\begin{array}{l}21 \\
7^{b}\end{array}$ & $\begin{array}{l}\text { Pre-mature } \\
\text { Maturation }^{\mathrm{b}}\end{array}$ \\
\hline Spent & $\begin{array}{l}\text { The ovaries were flaccid and } \\
\text { white or light yellow in color. } \\
\text { Some remaining mature } \\
\text { oocytes could be observed by } \\
\text { eyes }\end{array}$ & $\begin{array}{l}\text { Un-spawned mature oocytes } \\
\text { and some yolk platelet } \\
\text { oocytes were undergoing } \\
\text { re-sorption }\end{array}$ & $0.66 \pm 0.09$ & 8 & $\begin{array}{l}\text { Maturation or yolk } \\
\text { platelet (but atretic) }\end{array}$ \\
\hline Recovery & $\begin{array}{l}\text { Ovaries were thin and white, } \\
\text { and the ovarian wall was thick }\end{array}$ & $\begin{array}{l}\text { The most advanced oocytes } \\
\text { were at the pre-yolk stage, but } \\
\text { some of them underwent re- } \\
\text { sorption }\end{array}$ & $0.52 \pm 0.03$ & 44 & $\begin{array}{l}\text { Pre-yolk platelet } \\
\text { (but atretic) }\end{array}$ \\
\hline
\end{tabular}

a Denotes the re-developing stage

b

Denotes the re-ripe stage

$r^{2}=0.950, n=1036$, and $3 \mathrm{~mm}$ was used as the interval of size class. The mean and standard error for the $\mathrm{CL}$ at functional maturity $\mathrm{CL}_{50}$ was $66.63 \pm 1.07 \mathrm{~mm} \mathrm{CL}$ (Fig. 8).

For males, the allometric growth of both the right second and third meropodite (RSM and RTM) was described by two regression lines (Fig. 9a, b). Inflection points occurred at $72.21 \mathrm{~mm} \mathrm{CL}$ in RSM [slopes were $0.59 \pm 0.01$ (mean $\pm \mathrm{SE}$ ) and $1.03 \pm 0.04$, respectively] and $74.43 \mathrm{~mm} \mathrm{CL}$ in RTM (slopes were $0.63 \pm 0.01$ and $1.04 \pm 0.04$, respectively). For females, we failed to find the allometric growth of RSM (slope was $0.53 \pm 0.02)$ and RTM $(0.53 \pm 0.02)$ (Fig. 9a, b). An analysis of residual sum of square indicated that two regression lines fit better in RSM and RTM for males $(F$ test, $P<0.001)$.

Regression lines were statistically compared with each other on sex, size, and between appendages by ANCOVA. For males, slopes were significantly different between immature and mature individuals in RSM $(F=243.1, \quad P<0.01)$ and RTM $(F=194.7$, $P<0.01)$. Sex-specific growth of RSM $(F=4.88$, $P<0.05)$ and RTM $(F=11.43, P<0.01)$ was observed in this study, and the RSM grew larger than RTM for immature males $(F=4.84, P<0.05)$.

\section{Brood size}

The brood size of spiny lobster was size related, and brood size increased progressively with body size

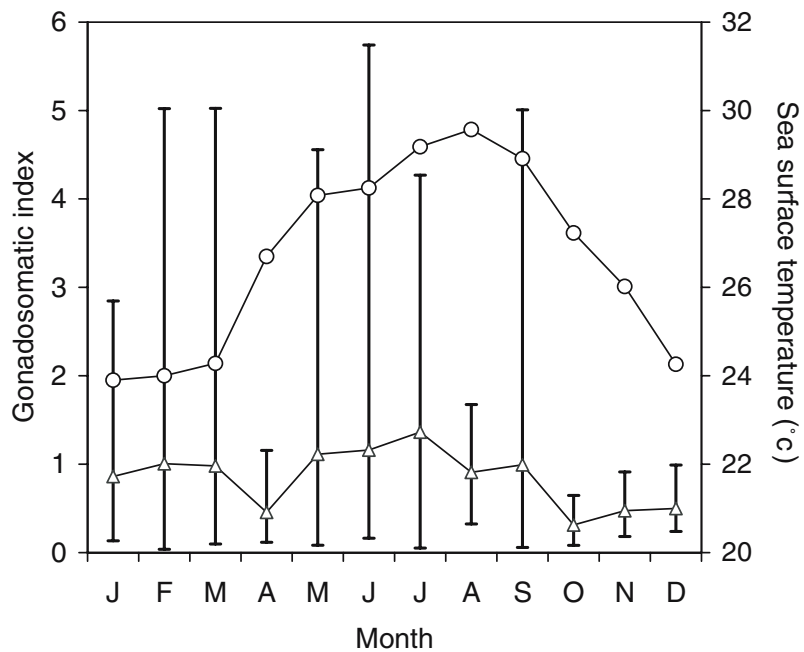

Fig. 5 Monthly variation in mean gonadosomatic index (GSI) of the female spiny lobster Panulirus penicillatus in Taitung (open triangle $=$ average, vertical bars $=$ ranges $)$, and the mean sea surface temperature off the Taitung coast (open circle) between January 2004 and December 2004 
Fig. 6 Monthly presence of egg-bearing Panulirus penicillatus by size class to December 2004. Number individuals. Asterisks denote no data pooled from September 2003 of bars show the number of

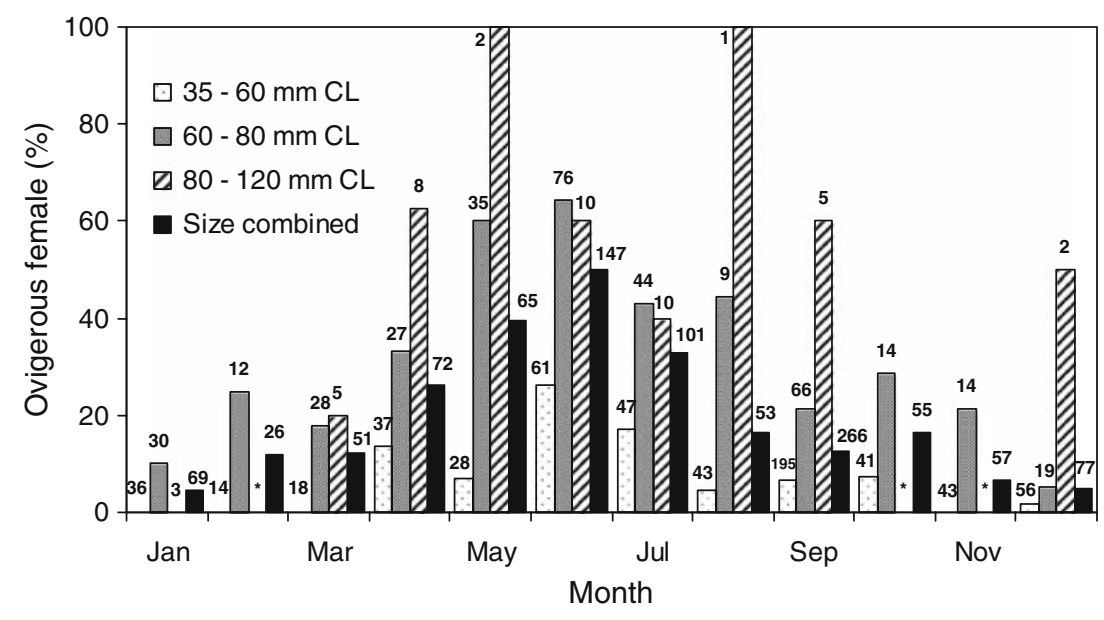

Fig. 7 Cumulative frequencies (\%) of individuals by month for each stage of ovarian development of the spiny lobster Panulirus penicillatus in Taitung

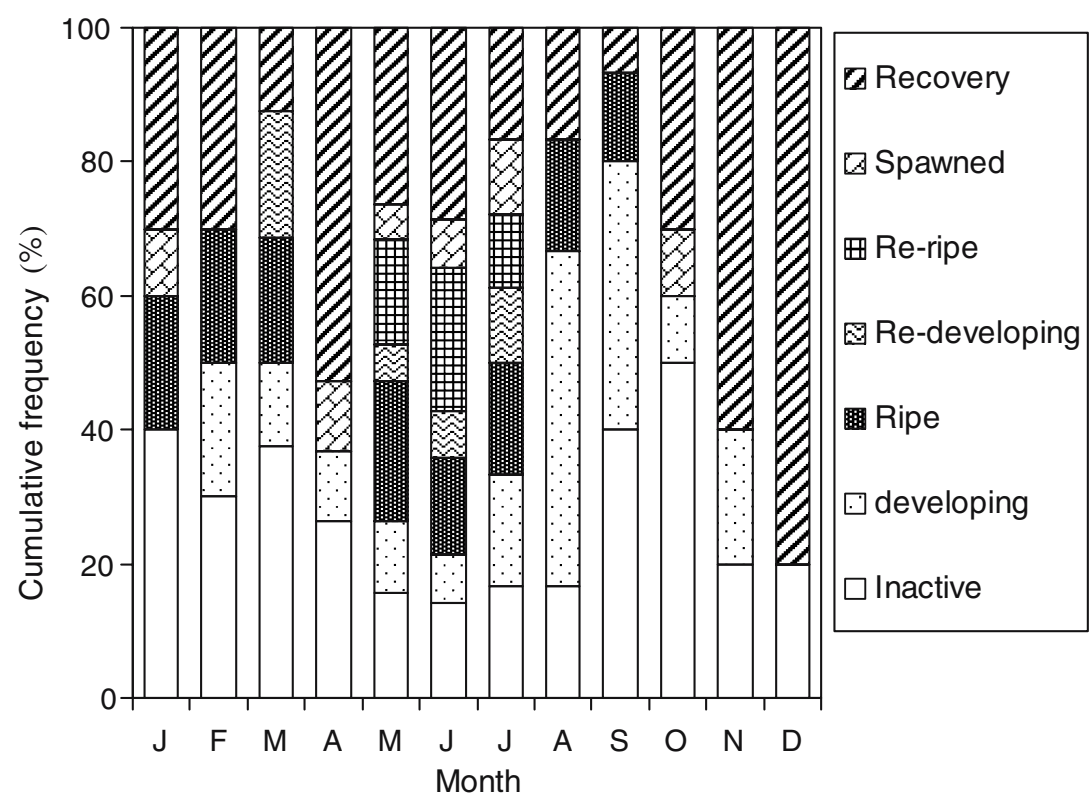

(Fig. 10). The relationship between CL and the number of oviposited eggs $\left(Y_{\mathrm{BS}}\right)$ over a size range of 44.51 to $80.54 \mathrm{~mm} \mathrm{CL}$ was estimated as:

$Y_{B S}=2.4 \times 10^{-3} C L^{4.18}$

$\left(r^{2}=0.902\right.$, and $\left.n=12\right)$

The total dried egg masses ranged from 0.63 to $6.66 \mathrm{~g}$. The mean number of eggs per $0.01 \mathrm{~g}$ subsample ranged from 253 to 265 eggs. The estimated total number of eggs over the sampled size range was from 16,399 to 173,090 eggs, and the mean egg size range was from 524 to $610 \mu \mathrm{m}$ in diameter. The number of eggs per body gram ranged from 204 to 537 eggs, and there were no significant relationships between the relative brood size and body size $(r=0.56, P>0.05)$ and between the egg size and brood size $(r=0.1$, $P>0.05)$.

Relative reproductive potential

The lobsters in the size class of $60-80 \mathrm{~mm}$ CL yielded $62.4 \%$ of the total egg production, highest among all size classes (Fig. 11). Lobsters smaller than $60 \mathrm{~mm} \mathrm{CL}$ contained more than $50 \%$ of the total commercial catch, but produced only $7.93 \%$ of the eggs. Lobsters in size class $95-100 \mathrm{~mm}$ CL had the highest productivity ratio $\left(P_{i}=E_{i} \% / C_{i}\right) 20.35 \%$, which made the lobsters in this size class were 2.7 times more productive than the lobsters in the $60-80 \mathrm{~mm}$ CL. 


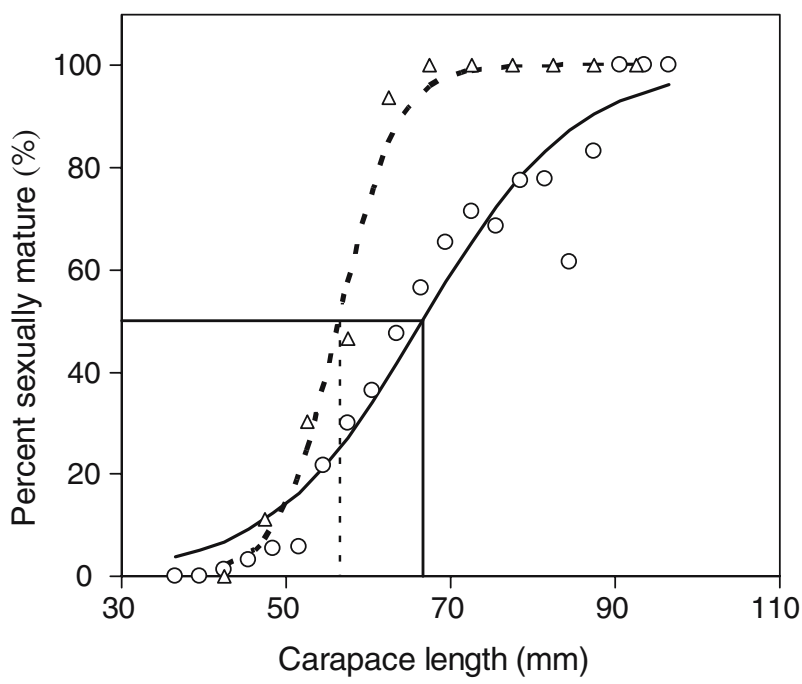

Fig. 8 Scatter plots and fitted curves for the relationship between body size (carapace length) and percent sexual maturity based on functional maturity gauged by presence-absence of sperm mass or berried condition (dark-line curve), and based on physiological maturity by microscopic examination of ovaries (dotted curve), and analogous perpendicular lines are median size $\left(\mathrm{CL}_{50}\right)$ at functional and physiological maturity, respectively

\section{Discussion and conclusions}

\section{Sex ratio}

The sex ratio of $P$. penicillatus was 1:1 in the present study, which differed from observations made in other studies. The sex ratio was biased towards males of $P$. penicillatus population in Hawaiian (McGinnis 1972), and in Red Sea (Hogarth and Barratt 1996). In contrast, the sex ratio of $P$. penicillatus favored females over males in Marshall Islands (0.71) (Ebert and Ford 1986), and in Gulf of Eilat (0.61) (Plaut and Fishelson 1991). The skewed sex ratio in theses studies might result from limited habitat coverage and use of single fishing gear over a relatively short time period in these studies because female and male lobsters tended to favor different habitats and have different susceptibility to different fishing gears (Hogarth and Barratt 1996; Ebert and Ford 1986). The samples of this study were collected with skin diving and trammel net and covered different habitats over a relatively long time period. Thus, the sex ratio tended to be more balanced and might reflect the true sex ratio of the $P$. penicillatus population in Taitung. Males dominated large size classes in the present study, which might result from sex-specific growth rate (Morgan 1980) or the reproductive cost of females (Briones-Fourzán and LozanoAlvarez 1992).

Females were more abundant than males in June, July and September 2004, which were the reproductive
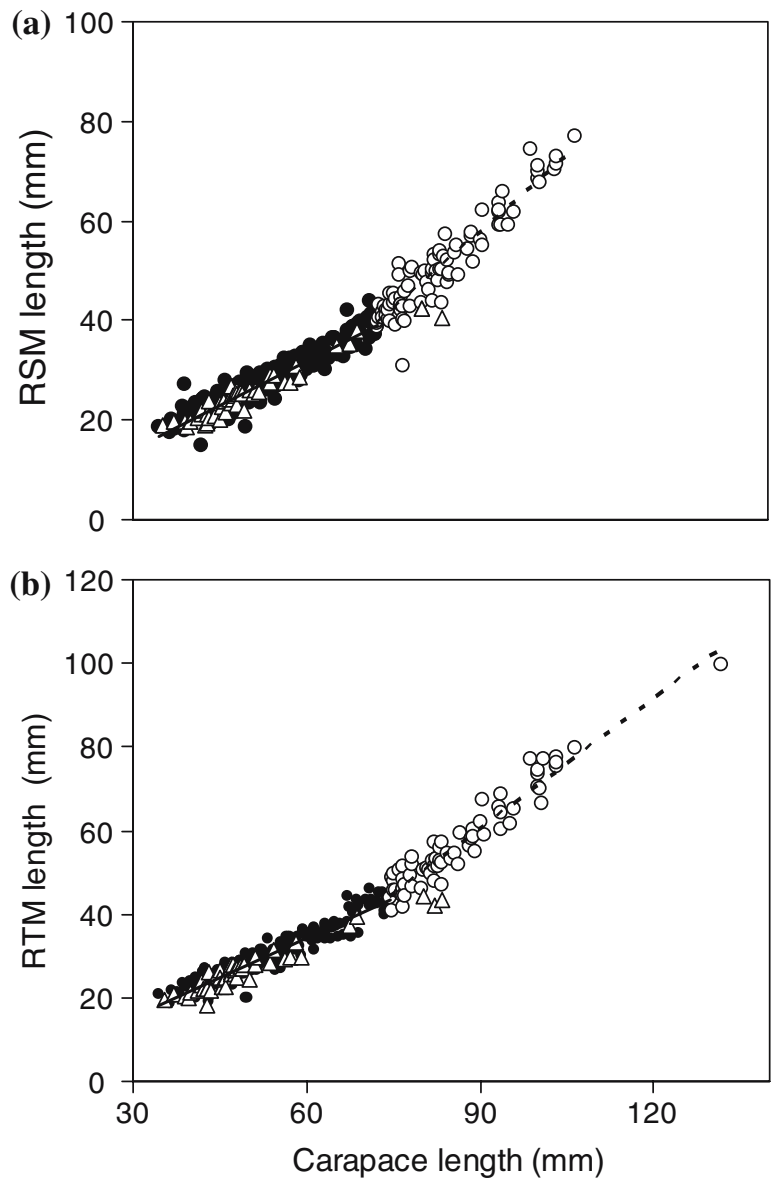

- Male (immature) $\circ$ Male (mature) $\Delta$ Female

Fig. 9 Scatter plots of the relationship between a right second meropodite (RSM) length and b right third meropodite (RTM) length and carapace length for the spiny lobster Panulirus penicillatus

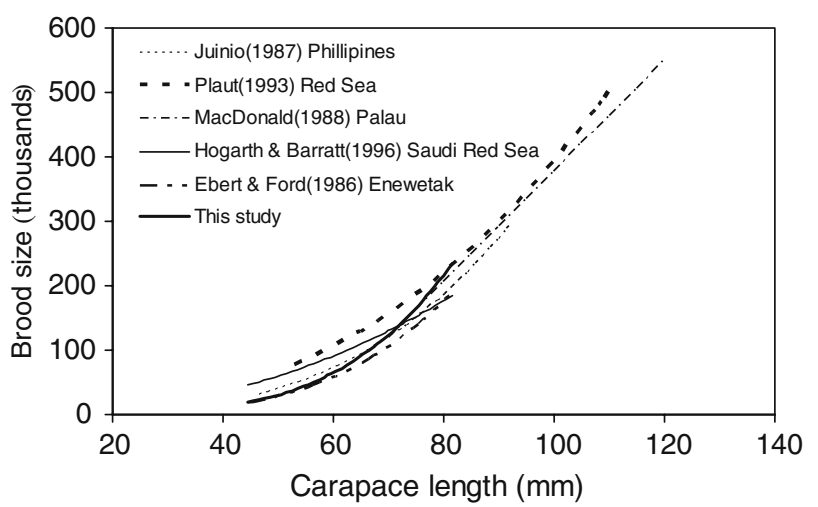

Fig. 10 Comparison of the relationships between carapace length and brood size of Panulirus penicillatus among various studies 


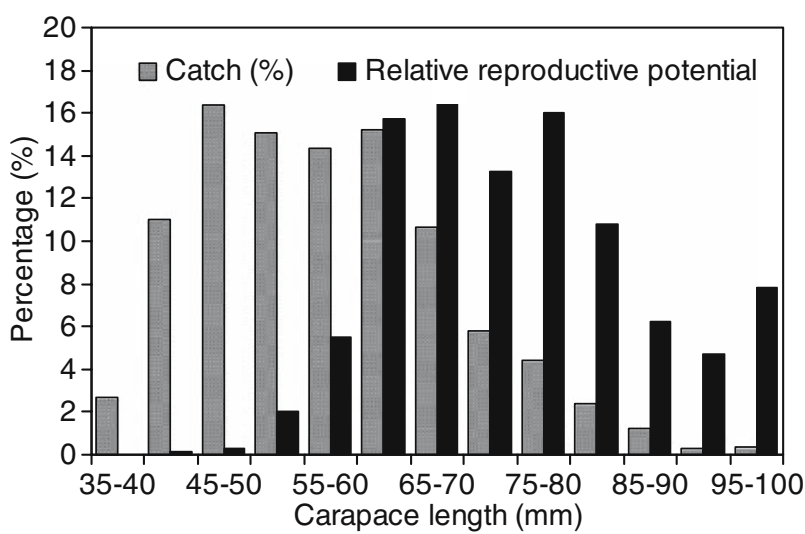

Fig. 11 Relative reproductive potential and the corresponding percentage of the commercial catch in Taitung, by 5-mm size class

season. This result tends to be contrary to the spawning behavior of female lobsters that usually display a more reclusive behavior and tend to occupy the deepest parts of the habitat during the spawning season (Kanciruk and Herrnkind 1976; Morgan 1980).

\section{Size at maturity}

For females, the estimate of size at $50 \%$ functional maturity was $66.63 \mathrm{~mm} \mathrm{CL}$, and the size at $50 \%$ physiological maturity was $56.46 \mathrm{~mm} \mathrm{CL}$. Size at maturity of $P$. penicillatus was found to have large spatial variations (Table 3 ). In the estimation of size at functional maturity, a necessary prerequisite is to accurately identify the maturation state. A histological analysis of the developmental stages of oocytes is the most accurate method for determining sexual maturity, because unberried but mature females are indistinguishable from external morphology (DeMartini et al. 2005). In addition, the sample size and sampling time and season covered by a study can also influence the result.

In this study, we found that mean GSI value can be used to distinguish different ovaries stages, although GSI can be influenced by a number of factors such as variations in weight-length relationships among individuals. The result was similar to that reported for $P$. japonicus by Minagawa and Sano (1997).

The difference in size at maturity can also result from biotic and abiotic environmental variables such as population density (Pollock 1995; DeMartini et al. 2003), temperature (Chittleborough 1976), food availability (Kanciruk 1980), and shelter (Polovina 1989). If we consider size at maturity is related to age (Fielder 1964), we may infer that the growth of $P$. penicillatus in Taitung is faster than that of lobsters in the other study sites. For males, the allometric growth of the walking leg after a pubertal molt provides useful estimates of size at functional maturity in male lobsters for $P$. versicolor (George and Morgan 1979), P. japonicus (Minagawa and Higuchi 1997), and P. guttatus (Robertson and Butler 2003).

The size at maturity for male $P$. penicillatus was calculated as $72.21 \mathrm{~mm} \mathrm{CL}$ and $74.43 \mathrm{~mm} \mathrm{CL}$ by RSM and RTM, respectively. This suggests that the RSM and RTM provide approximate estimates and can be useful for determining the functional maturity for males. A similar size at maturity of $70 \mathrm{~mm} \mathrm{CL}$ was determined by the allometric growth of the third

Table 3 A comparison of the estimated size at sexual maturity of the spiny lobster Panulirus penicillatus among various studies. SAM is the size at maturity (in $\mathrm{mm} \mathrm{CL}$ )

\begin{tabular}{|c|c|c|c|}
\hline Area & Author & Method & SAM \\
\hline Oahu, Hawaii & MacDonald (1979) & Based on the average CL of berried female & 98 \\
\hline Palau & MacDonald (1979) & Based on the average CL of berried female & 100 \\
\hline Enewetak Atoll, Marshall Islands & Ebert and Ford 1986 & Based on the smallest berried female & 62 \\
\hline Cagayan, Philippines & Juinio (1987) & $\begin{array}{l}\text { Based on the average CL of mated } \\
\text { or berried female }\end{array}$ & $45-49.9$ \\
\hline Western Caroline Islands, Palau & MacDonald (1988) & Based on the smallest berried female & 69 \\
\hline Gulf of Eilat, Red Sea & Plaut (1993) & $\begin{array}{l}\text { Incidence of mated or berried females } \\
\text { Relationship between CL and the } \\
\text { Pleopodal exopodite length }\end{array}$ & 50 \\
\hline Saudi Red Sea & Hogarth and Barratt 1996 & $\begin{array}{l}\text { Incidence of mated or berried females } \\
\text { Relationship between CL and the } \\
\text { 2nd or 3rd pereiopod } \\
\text { Smallest berried female }\end{array}$ & $40-50$ \\
\hline Taitung coast, Taiwan & This study & $\begin{array}{l}\text { Incidence of mated or berried females } \\
\text { Histological analysis }\end{array}$ & $\begin{array}{l}66.63^{\mathrm{a}} \\
56.46^{\mathrm{b}}\end{array}$ \\
\hline
\end{tabular}

\footnotetext{
a Denotes size at $50 \%$ functional maturity

b Denotes size at $50 \%$ physiological maturity
} 
walking leg length in Juinio (1987). For females, RSM or RTM fails to produce a morphological index to discriminate between mature and immature lobsters, as in the study of Plaut (1993) by first and fifth limb length and in P. versicolor (George and Morgan 1979).

\section{Reproductive cycle}

The major spawning season of $P$. penicillatus in Taitung is from May to September, based on the monthly pattern of ovarian development, the percentage of ovigerous females and GSI. $P$. penicillatus in the northern hemisphere were reported to spawn actively throughout a year, with high spawning season during summer (Morris 1968; MacDonald 1979, 1988; Ebert and Ford 1986; Juinio 1987; Plaut 1993). This high breeding activity in summer results from higher temperature (Fig. 5; Plaut 1993). In this study, the appearance of re-developing and re-ripe stage ovary from May to July suggests that females recover quickly for repeating spawning results from higher temperature (Figs. 5, 7).

An examination of monthly presence of egg-bearing by size class of $P$. penicillatus indicates that spawning season may be size-specific (Fig. 6). Large females (>60 mm CL) tend to spawn early in spring, whereas smaller females $(<60 \mathrm{~mm} \mathrm{CL})$ spawn in summer. It is difficult to numerate how many time lobsters of a given size class spawn in a year (Juinio 1987; Plaut 1993).

The lobsters of size greater than $60 \mathrm{~mm} \mathrm{CL}$ observed have more re-developing and re-ripe ovaries than smaller lobsters ( $<60 \mathrm{~mm}$ CL; Fig. 12), and the smallest re-developing female identified in this study was $57 \mathrm{~mm} \mathrm{CL}$. This suggests that large mature

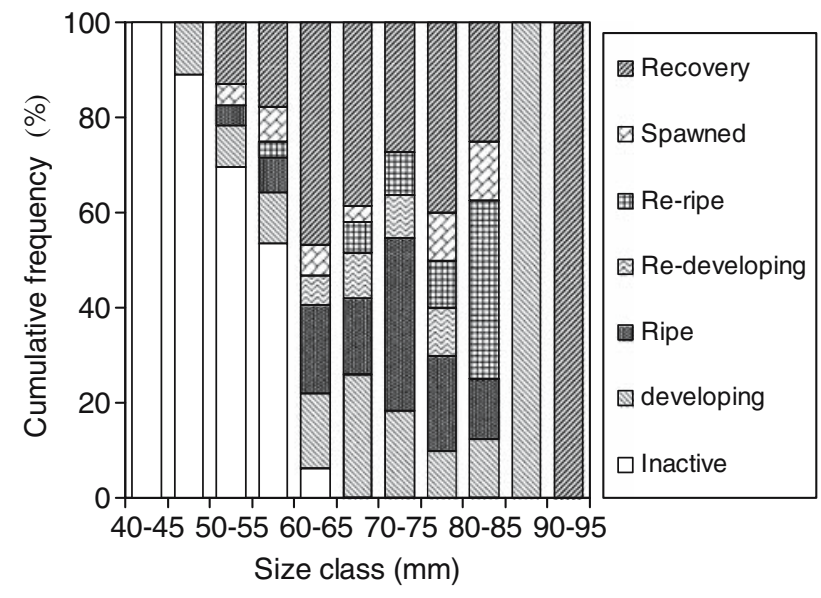

Fig. 12 Cumulative frequencies (\%) of individuals by size class (5-mm carapace length) for each stage of ovarian development of the spiny lobster Panulirus penicillatus from Taitung, Taiwan females ( $>60 \mathrm{~mm} \mathrm{CL}$ ) spawn at least three times a year while smaller newly mature females spawn at least once. For other $P$. penicillatus populations, mature females are estimated to spawn 2-4 times in Red Sea and up to four times a year in Philippines (Plaut 1993; Juinio 1987). The tropical Panulirus species may spawn year round when they are not molting (Chubb 2000).

\section{Brood size}

The relationship between $\mathrm{CL}$ and brood size in $P$. penicillatus from Taitung was curvilinear, as found in the Philippines (Juinio 1987) and the Red Sea (Plaut 1993; Hogarth and Barratt 1996), but MacDonald (1988) showed a linear relationship in Palau. The difference may result from different size ranges of samples. In general, lobsters with the same CL tend to yield similar numbers of eggs regardless of the relationship (Chubb 2000). Spatial variations in CL-brood size relationships were reported in certain subtropical and temperate lobsters (Chubb 2000). Although the sample size of this study is not large, the relationship between CL and brood size in females of $P$. penicillatus in Taitung is consistent with that for other populations (MacDonald 1979; Juinio 1987; Plaut 1993; Hogarth and Barratt 1996; Fig. 10). This confirms the result of Plaut (1993) who suggests that the relationship between CL and brood size is constant in P. penicillatus over a wide range of environment conditions.

Many lobster species have reduction in brood size for repeat spawning within the same season (Chubb 2000). Previous studies did not evaluate variations in repetitive brood sizes of $P$. penicillatus (Juinio 1987; Plaut 1993). By comparing GSI of the developing and ripe stage ovaries with the re-developing and re-ripe stage ovaries, we found that the number of eggs in the second spawning event in a given year tended to be smaller than that in the first spawning.

Reproductive senescence was noted in the large females of some spiny lobsters (Chubb 2000). Goñi et al. (2003) showed that maximum relative brood size occurred in the median size class of the $P$. elephas population in the mediterranean, and the egg size tended to increase with body size. The relative brood size and egg size were not significantly related to the body size and brood size of $P$. penicillatus in Taitung. This is similar to what was observed for the $P$. penicillatus in Philippines (Juinio 1987).

Relative reproductive potential

Relative reproductive potential can serve to determine the size class of spawning females that make the 
greatest contribution to the egg production in a population (Kanciruk and Herrnkind 1976). Female lobsters of $60-80 \mathrm{~mm}$ CL make the greatest contributions to egg production, and more than $50 \%$ of the females in commercial catch had their sizes smaller than or equal to $60 \mathrm{~mm} \mathrm{CL}$ in Taitung (Fig. 11). This indicated that the smaller lobsters $(\leq 60 \mathrm{~mm} \mathrm{CL})$ contributed lower egg production (7.93\%), but consisted of a large part of the commercial catch.

The minimum legal size (MLS) should be established at a size that allows each individual an opportunity to reproduce at least once before reaching the exploitable size (Jamieson 1993). In the present study, the size at $50 \%$ physiological maturity of females was $56.46 \mathrm{~mm}$ CL (about 3 years old, Chen 2005). Current MLS protects $54.36 \%$ of egg production potential, and thus tends to be effective in conserving egg production. However, this MLS is $16.61 \mathrm{~mm}$ larger than the size at maturity, which may be overcautious in the long term.

An implementation of a MLS of $65 \mathrm{~mm}$ CL would have less impact on the overall egg production because of low RRP of lobsters in these size classes. However, such a regulation may be necessary. It can allow lobsters to reproduce at least once before reaching the harvestable size and protect $23.68 \%$ of population egg production.

The lobsters that have the re-developing and re-ripe stages of ovary had an average size of $70.4 \mathrm{~mm} \mathrm{CL}$, and the lobsters in size class $95-100 \mathrm{~mm}$ CL had the highest productivity ratio $(20.35 \%)$. Thus, large females are important for the egg production because they are highly fecund, produce large and high quality of eggs and are capable of spawning multiple times annually.

Introducing a maximum legal size (MALS) of $90 \mathrm{~mm} \mathrm{CL}$ can protect $12.59 \%$ population egg production capacity, even though only $0.68 \%$ of the catch falls in this size ( $\geq 90 \mathrm{~mm} \mathrm{CL}$ ). This strategy, however, may have side effects because it may lead to an increased exploitation of the remaining legal-size females (Hobday and Ryan 1997). However, given the small number of catch in this size range, this possible side effect may not be significant for the Taitung lobster fishery. If the implementation of MLS (65 $\mathrm{mm} \mathrm{CL})$ and the MALS $(90 \mathrm{~mm} \mathrm{CL})$ can be introduced at the same time, we would protect $36.27 \%$ of the total egg production.

\section{Conclusions}

The spiny lobsters, $P$. penicillatus, had an extended spawning time period throughout a year in Taitung, although spawning was most intense between May and
September. The presence of highly reproductive females and repetitive spawning during the summer spawning season in Taitung coastal water were linked to higher water temperature. Spatial variations of size at maturity were found in $P$. penicillatus. For females the size at $50 \%$ physiological maturity was $56.46 \mathrm{~mm} \mathrm{CL}$, size at $50 \%$ functional maturity was $66.63 \mathrm{~mm} \mathrm{CL}$ and for males size at functional maturity was between 72 and $74 \mathrm{~mm}$ CL. There was a curvilinear relationship between brood size and carapace length, with an average of 0.1 million eggs in females ranging in size from 44.51 to $80.54 \mathrm{~mm} \mathrm{CL}$. If we implemented the MLS (65 mm CL) and MALS (90 $\mathrm{mm} \mathrm{CL}$ ) at the same time, it would increase the egg production potential of the population. The study of relative reproductive potential provides us with the critical information needed for the establishment of size limit regulation. However, a better understanding of the lobster population dynamics requires a better understanding of key life history processes such as growth, mortality, and larval dispersal mechanism of $P$. penicillatus. An establishment of a realistic population dynamics model that mimics the lobster life history and the fishery process should be the focus of future research for the lobster population in Taitung.

Acknowledgments The authors express their sincere gratitude to the lobster wholesaler Mr. Chen for offering the lobster specimens and to the anonymous referees for their valuable comments. This study was in part supported financially by the National Science Council of Taiwan through the grant NSC952313-B-002-065 to Chi-Lu Sun.

\section{References}

Aiken DE, Waddy SL (1980) Reproductive biology. In: Cobb JS, Phillips BF (eds) The biology and management of lobsters, physiology and behavior. Academic, New York, pp 215-276

Beyers CJ, Goosen PC (1987) Variations in fecundity and size at sexual maturity of female rock lobster Jasus lalandii in the Benguela ecosystem. S Afr J Mar Sci 5:513-521

Briones-Fourzán P, Lozano-Alvarez E (1992) Aspects of the reproduction of Panulirus inflatus (Bouvier) and $P$. gracilis Streets (Decapoda: Palinuridae) from the Pacific coast of Mexico. J Crust Biol 12:41-50

Chambers JM, Hastie TJ (1992) Statistical models in S. Advanced Books and Software, Pacific Grove, CA

Chen YK (2005) Age, growth, morality and yield-per-recruit analysis based on length data for the spiny lobster Panulirus penicillatus in coastal waters off southeastern Taiwan. MS thesis. Institute of Oceanography, Taipei

Chittleborough RG (1976) Breeding of Panulirus longipes Cygnus George under natural and controlled conditions. Aust J Mar Freshw Res 27:499-516

Chubb CF (2000) Reproductive biology: issues for management. In: Phillips BF, Kittaka J (eds) Spiny lobsters: fisheries and culture, 2nd edn. Fishing New Books, Blackwell, Oxford, pp 245-275 
DeMartini EE, DiNardo GT, Williams HA (2003) Temporal changes in population density, fecundity and egg size of the Hawaiian spiny lobster, Panulirus marginatus, at Necker Bank, Northwestern Hawaiian Islands. Fish Bull 101:22-31

DeMartini EE, McCracken ML, Moffitt RB, Wetherall JA (2005) Relative pleopod length as an indicator of size at sexual maturity in slipper Scyllarides squammosus and spiny Hawaiian Panulirus marginatus lobsters. Fish Bull 103:23-33

Ebert TA, Ford RF (1986) Population ecology and fishery potential of the spiny lobster Panulirus penicillatus at Enewetak Atoll, Marshall Islands. Bull Mar Sci 38:56-67

Evans CR, Lockwood APM, Evans AJ, Free E (1995) Field studies of the reproductive biology of the spiny lobsters Panulirus argus (Latreille) and $P$. guttatus (Latreille) at Bermuda. J Shellfish Res 14:371-381

Fielder DR (1964) The spiny lobster, Jasus lalandei (H* MilneEdwards), in South Australia. II. Reproduction. Aust J Mar Freshw Res 15:133-144

George RW (1972) South Pacific Islands-Rock Lobster Resources. Rep. S. Pac. Is. Fish. Dev. Ag. Rome. UN / FAO. 42 pp

George RW, Morgan GR (1979) Linear growth stages in the rock lobster Panulirus versicolor as a method for determining size at first physical maturity. Rapp P -V Reun Cons Int Explor Mer 175:182-185

Gomez ED, Juinio MA, Bermas NA (1994) Reproduction of Panulirus longipes longipes in Calatagan, Batangas, Philippines. Crustaceana 67:110-120

Goñi R, Quetglas A, Reñones O (2003) Size at maturity, fecundity and reproductive potential of a protected population of the spiny lobster Palinurus elephas (Fabricius, 1787) from the western Mediterranean. Mar Biol 143:583592

Hobday DK, Ryan TJ (1997) Contrasting size at sexual maturity of southern rock lobster Jasus edwardsii in the two Victorian fishing zone implication for total egg production and management. Aust J Mar Freshw Res 48:1009-1014

Hogarth PJ, Barratt LA (1996) Size distribution, maturity and fecundity of the spiny lobster Panulirus penicillatus (Olivier 1791) in the Red Sea. Trop Zool 9:399-408

Jamieson GS (1993) Marine invertebrate conservation: evaluation of fisheries over-exploitation concerns. Am Zool 33:551-567

Juinio MA (1987) Some aspects of the reproduction of Panulirus penicillatus (Decapoda: palinuridae). Bull Mar Sci 41:242252

Kanciruk P (1980) Ecology of juvenile and adult Palinuridae (Spiny lobsters). In: S. CJ, Phillips BF, (eds) The Biology and Management of Lobsters, vol II. Ecology and management. Academic Press, New York, pp 59-92

Kanciruk P, Herrnkind WF (1976) Autumnal reproduction in Panulirus argus at Bimini, Bahamas. Bull Mar Sci 26:417432

Lovett DL, Felder DL (1989) Application of regression techniques to studies of relative growth in crustaceans. J Crust Biol 9:529-539
MacDonald CD (1979) Management aspect of the biology of the spiny lobsters, $P$. marginatus, $P$. penicillatus, $P$. versicolor and $P$. longipes femoristriga in Hawaii and the Western Pacific. Final Report to the Western Pacific Regional Fishery Management Council, Honolulu, Hawaii. 46 pp

MacDonald CD (1988) Fecundity and reproductive rates in Indo-West Pacific spiny lobsters. Micronesica 21:103-114

McGinnis F (1972) Management investigation of two species of spiny lobster, Panulirus japonicus and Panulirus penicillatus. Report of Hawaii Division of Fish and Game, Honolulu, 51 $\mathrm{pp}$

Minagawa M (1997) Reproductive cycle and size-dependent spawning of female spiny lobsters Panulirus japonicus off Oshima island, Tokyo, Japan. Aust J Mar Freshw Res 48:869-874

Minagawa M, Higuchi S (1997) Analysis of size, gonadal maturation, and functional maturity in the spiny lobster Panulirus japonicus (Decapoda: Palinuridae). J Crustac Biol 17:70-80

Minagawa M, Sano M (1997) Oogenesis and ovarian development cycle of the spiny lobster Panulirus japonicus (Decapoda: Palinuridae). Aust J Mar Freshw Res 48:875-887

Morgan GR (1980) Population dynamics of spiny lobsters. In: Cobb JS, Phillips BF (eds) The biology and management of lobsters. Academic, New York, pp 189-217

Morris DE (1968) Some aspects of the commercial fishery and biology of two species of the spiny lobster, Panulirus japonicus (De Siebold) and Panulirus penicillatus (Oliver), in Hawaii. MS thesis, Honolulu

Plaut I (1993) Sexual maturity, reproductive season, and fecundity of the spiny lobster Panulirus penicillatus from the Gulf of Eilat (Aqaba), Red Sea. Aust J Mar Freshw Res 44:527535

Plaut I, Fishelson L (1991) Population structure and growth in captivity of the spiny lobster Panulirus penicillatus from Dahab, Gulf of Aqaba, Red sea. Mar Biol 111:467-472

Pollock DE (1995) Changes in maturation ages and sizes in crustacean and fish populations. S Afr J Mar Sci 15:99-103

Pollock DE, Goosen PC (1991) Reproductive dynamics of two Jasus species in the south Atlantic region. S Afr J Mar Sci 10:141-147

Polovina JJ (1989) Density dependence in spiny lobster, Panulirus marginatus, in the Northwestern Hawaiian Islands. Can J Fish Aquat Sci 46

Robertson DN, Butler IV MJ (2003) Growth and size at maturity in the spotted spiny lobster, Panulirus guttatus. J Crustac Biol 23:265-272

Somerton DA (1980) A computer technique for estimating the size of sexual maturity in crabs. Can J Fish Aquat Sci 47:1488-1494

Taiwan Provincial Government (1987) Taiwan fisheries management regulations (in Chinese) 